\title{
Effect of Spiritual Intelligence on Leadership Effectiveness and Food-hygiene Practices
}

\author{
Mazni Saad ${ }^{1}$, Toh Poh See², Mohamed Azam Mohamed Adil3 \\ Normalini Md Kassim ${ }^{4}$
}

\author{
${ }^{1}$ Kulliyah of Languages and Management, \\ International Islamic University Malaysia, Malaysia \\ ${ }^{2}$ Faculty of Hotel and Tourism Management, \\ ${ }^{3}$ Academy of Contemporary Islamic Studies, \\ Universiti Teknologi MARA, 40450 Shah Alam, Selangor, Malaysia \\ ${ }^{4}$ School of Management, \\ Universiti Sains Malaysia,11800 USM, Penang, Malaysia \\ ms_mazni1971@yahoo.com
}

\begin{abstract}
This study suggests an effort through a Holistic View of spiritual intelligence to address low-quality food problem at public institutions in East Malaysia. It explored the causal relationship of this value to Food Performance, Leadership Effectiveness, and Food-Hygiene Practice through 210 food handlers. The Partial Least Square Structural Equation Modeling (PLS-SEM) was used to test the relationship. Holistic View was found to have a positively significant relationship with the performance but, not Leadership Effectiveness. Holistic View among food handlers was found unaffected by Food hygiene practices.

Keywords: Spiritual intelligence; leadership effectiveness; food-hygiene practices; foodservice performance

eISSN 2514-7528 @ 2018. The Authors. Published for AMER ABRA cE-Bs by e-International Publishing House, Ltd., UK. This is an open-access article under the CC BY-NC-ND license (http://creativecommons.org/licenses/bync-nd/4.0/). Peer-review under responsibility of AMER (Association of Malaysian Environment-Behaviour Researchers), ABRA (Association of Behavioural Researchers on Asians) and cE-Bs (Centre for EnvironmentBehaviour Studies), Faculty of Architecture, Planning \& Surveying, Universiti Teknologi MARA, Malaysia.

DOI: https://doi.org/10.21834/jabs.v3i10.306
\end{abstract}




\subsection{Introduction}

A food service institution in the hospitality industry refers to a catering business that provides meals to places like skilled nursing facilities, senior housing, hospitals and intermediate care facilities. It is a meals business that must keep up with today's healthy lifestyle demands for food to be tasty, healthy and safe and most importantly cooked by a committed team of food handlers who are reliable in preparing healthy meals in a healthy working environment.

\subsection{Problems in Foodservice Institutions}

Food service institutions in Malaysia often have to deal with a diverse workforce that is highly mobile and lacking in work commitment. Foreigners further inflate this diversity as the industry is easily accessible to unskilled workers on a temporary employment pass and who usually work for a low flat wage. High employee turnover is, therefore, a great challenge. Poor sources of raw material, lack of food preparation standards and inadequate infrastructure also pose a problem although not as critical as incompetent food handlers who either have very little or no knowledge of food hygiene practices. They directly contribute to poor quality food in these establishments. This study, therefore, suggests developing food handlers' Holistic View of Spiritual Intelligence to address low-quality food problem at these foodservice establishments.

\subsection{Literature Review}

\subsection{Spiritual Intelligence}

Spiritual intelligence (or spiritual quotient) (SQ) is discussed with emotional intelligence (or emotional quotient) (EQ) and successful performance. EQ's abilities and skills controlling personality are extended to $S Q$, a subset of social intelligence (Mazni, Toh, Mohamed Azam, \& Siti Khadijah, 2014). SQ comprises intangible inner attributes that enable one to care, tolerate and adapt (Marques, 2005). It also leads to a clear and stable sense of self-identity that allows one to discern the meaning of work events and circumstances. Employees will become more focused and calm at work, develop a selfless and altruistic attitude towards interpersonal relationships and easily facilitate changes and barriers (George, 2006). SQ is the foundation for healthy workplace relationships that leads to the carrying out of tasks beyond a job's boundary (Kumar \& Bhasin, 2014). SQ is defined as the soul's intelligence, with which we heal ourselves and make ourselves whole (Zohar and Marshall, 2001).

\subsection{A Holistic View}

In some cultures, people find meaning and purpose in life through faith and devotion to one true God. Faith, spiritual strength, positive thinking, and appreciation of religion are all incarnated in SQ. It is a spiritual and Holistic View of an individual's identity - perception, cognition, plans, values, goals, motives, biological factors, conduct, and others (Magnusson \& Torestad, 1993). Besides, a person who expects rewards only from God always performs and strives for the best without thinking of other interests like recognition and monetary 
values (Magnusson and Torestad, 1993).

Spirituality and religion often confuse people, but active religion presents absolute realities in life (Gupta, Kumar, \& Singh, 2014). Religion is narrower and relates to behaviors, tends to be rigid and sometimes without any clear link to ethics (Fry, 2003). Religion too has been referred to continuously in solving problems (Kadkhoda \& Jahani, 2012; Lewis, Ritchie, \& Bates, 2011; McAdamis, 2011; Rostami \& Gol, 2014; Vayalilkarottu, 2012).

\subsection{Hypotheses Testing}

\subsubsection{Food-hygiene Practice and Holistic View}

Hygiene practice is linked to Holistic View in Mortell, Balkhy, Tannous, and Jong (2013) where hand hygiene compliance among physicians improved only with evidence. A therapeutic practice for late-life anxiety demonstrates substantial improvement in worry symptoms among older adults with beliefs rooted in religion (Barrera, Zeno, Bush, Barber, \& Stanley, 2012). Elements of food hygiene practices that complement religious faith have a positive relationship with Holistic View and should be incorporated into safe and healthy food practices (Mazni, Toh, Mohd Faiz Foong, \& Norazmir, 2013).

H1: Food-Hygiene Practice has an impact on Holistic View

\subsubsection{Leadership Effectiveness and Holistic View}

Intelligence is important in managing capabilities but not so with Australian educational institutions (Grunes, Gudmundsson, \& Irmer, 2014). Ronay and Carney (2013) also found testosterone negatively related to empathic accuracy and perceived leadership ability. However, 87 researchers found a link in the spiritual leadership of management practitioners (Dent, Higgins, \& Wharff, 2005). This study does not investigate the spiritual value of leaders but instead examines leadership effectiveness from the perception of subordinates.

H2: Perceived Leadership Effectiveness has an impact on Holistic View

\subsubsection{Holistic View and Food Performance}

A foodservice manager assesses company's performance by gauging how its food measures to others in the same industry. This study, however, looks at how religious and spiritual intelligence affect food performance. In investigating the financial performance of Turkish organizations, Ayranci (2011) found the Holistic View of top managers to have the strongest effect. Similarly, SQ positively impacted the service quality of a Counseling Center in Tehran (Rostami \& Gol, 2014). Eliasi and Dwyer (2002), on the other hand, linked dietary food intake and practices to an observance of traditions and religious guidelines, especially for Judaism and Islam. This study expects the religious value to be connected to performance. H3: Holistic View has an impact on Food Performance 


\subsection{Methodology}

The questionnaire adopted the 6-point Likert scale to elicit a more specific respondent reaction (Croasmun \& Ostrom, 2011). Holistic View is a component in the Integrated Spiritual Intelligence Scale (ISIS) and contains items adapted from Ayranci (2011). They refer to a connection with nature, ability to see problems as a whole, and recognition that everything is integrated. Items for Food-Hygiene Practices were taken from Bolton, Meally, Blair, McDowell, and Cowan (2008) and cross-checked against the Self-Examination Programme (SELF) developed by the Malaysian Ministry of Health. Question items for Leadership Effectiveness were adapted from Yukl (2008) and Food Performance from Kleynhans (2003). Judgmental sampling was chosen to generalize the results. The Partial Least Square Structural Equation Modeling (PLS-SEM) with SmartPLS 3.0 tested the model and hypotheses.

\subsection{Results and Discussions}

Table 1: Profile of Respondents

\begin{tabular}{|c|c|c|c|c|}
\hline Construct & Item & Loading & $\mathrm{AVE}^{\circ}$ & $\mathrm{CR}^{6}$ \\
\hline Food-Hygiene Practices & $\begin{array}{l}\text { Cutting board } \\
\text { Dented } \\
\text { Gloves } \\
\text { Headcover } \\
\text { Work when sick } \\
\text { Towel }\end{array}$ & $\begin{array}{l}0.599 \\
0.858 \\
0.780 \\
0.860 \\
0.696 \\
0.547\end{array}$ & 0.538 & 0.872 \\
\hline Leadership Effectiveness & $\begin{array}{l}\text { Contribution } \\
\text { Decision } \\
\text { Problem solver } \\
\text { Reflection }\end{array}$ & $\begin{array}{l}0.744 \\
0.911 \\
0.630 \\
0.810\end{array}$ & 0.609 & 0.860 \\
\hline Holistic View & $\begin{array}{l}\text { Closeness } \\
\text { Religious } \\
\text { Religious activities } \\
\text { Religious book }\end{array}$ & $\begin{array}{l}0.700 \\
0.889 \\
0.867 \\
0.723\end{array}$ & 0.639 & 0.875 \\
\hline Leadership Effectiveness & $\begin{array}{l}\text { Contribution } \\
\text { Decision } \\
\text { Problem solver } \\
\text { Reflection }\end{array}$ & $\begin{array}{l}0.744 \\
0.911 \\
0.630 \\
0.810\end{array}$ & 0.609 & 0.860 \\
\hline Holistic View & $\begin{array}{l}\text { Closeness } \\
\text { Religious } \\
\text { Religious activities } \\
\text { Religious book }\end{array}$ & $\begin{array}{l}0.700 \\
0.889 \\
0.867 \\
0.723\end{array}$ & 0.639 & 0.875 \\
\hline Food Performance & $\begin{array}{l}\text { Food presentation } \\
\text { Food temperature } \\
\text { Menu } \\
\text { Quality } \\
\text { Tasty }\end{array}$ & $\begin{array}{l}0.822 \\
0.699 \\
0.686 \\
0.668 \\
0.820\end{array}$ & 0.550 & 0.859 \\
\hline \multicolumn{5}{|c|}{$\begin{array}{l}\text { Note: Sink, Watch, and Needs were deleted due to low loadings } \\
\text { "Average variance extracted (AVE) = (summation of the square of the factor } \\
\text { loadings)/(summation of the square of the factor loadings) + (summation of the error variances) } \\
\text { "Composite reliability (CR) = (square of the summation of the factor loadings) (square of the } \\
\text { summation of the factor loadings) + (square of the summation of the error variances) }\end{array}$} \\
\hline
\end{tabular}


The validity and reliability of the measures follow the structural model for the testing of a hypothesized relationship. In which it is consistent with the views of Joseph F. Hair, Hult, Ringle, and Sarstedt (2014), T. Ramayah, Lee, and Boey (2011), and T. Ramayah, Yeap, and Ignatius (2013). The bootstrapping method of 500 resamples tested the significance of the path coefficients and the loadings (Gholami, Sulaiman, Ramayah, \& Molla, 2013).

Table 1 shows respondents from East Malaysia (54\% female); with $80 \%$ below 40 years old. The majority were permanent or contract workers and engaged in more than 8 hours of work daily. More than $80 \%$ worked for less than five years, most had attended food handling courses and had typhoid immunization.

\subsection{Measurement Model}

Table 2: Results of measurement model

\begin{tabular}{|c|c|c|c|c|}
\hline Construct & tem & Loadings & AVE $^{2}$ & $C R^{2}$ \\
\hline \multirow[t]{6}{*}{ Focd-Hyglene Practices } & Cutting board & 0.599 & 0.538 & 0.872 \\
\hline & Dented & 0.858 & & \\
\hline & Gloves & 0.780 & & \\
\hline & Headoover & 0.860 & & \\
\hline & Work when sick & 0.696 & & \\
\hline & Towel & 0.547 & & \\
\hline Leaderahlp & & & 0.609 & 0.850 \\
\hline \multirow[t]{4}{*}{ Emectiveness } & Contribution & 0.744 & & \\
\hline & Decision & 0.911 & & \\
\hline & Probiem solver & 0.630 & & \\
\hline & Reflection & 0.810 & & \\
\hline \multirow[t]{4}{*}{ Holsoc Vlew } & Closeness & 0.700 & 0.639 & 0.875 \\
\hline & Relghous & 0.889 & & \\
\hline & Reinglous activttes & 0.857 & & \\
\hline & Religlous book & 0.723 & & \\
\hline Leaderahtp & & & 0.809 & 0.850 \\
\hline \multirow[t]{4}{*}{ Emectiveness } & Contribution & 0.744 & & \\
\hline & Decialon & 0.911 & & \\
\hline & Problem solver & 0.630 & & \\
\hline & Reflection & 0.810 & & \\
\hline \multirow[t]{4}{*}{ Holsete Vlew } & Closeness & 0.700 & 0.639 & 0.875 \\
\hline & Relolous & 0.889 & & \\
\hline & Relglous activtles & 0.857 & & \\
\hline & Relglous book & 0.723 & & \\
\hline \multirow[t]{5}{*}{ Food Pertormance } & Food presentation & 0.822 & 0.550 & 0.859 \\
\hline & Food temperature & 0.699 & & \\
\hline & Menu & 0.686 & & \\
\hline & Qualty & 0.658 & & \\
\hline & Tasty & 0.820 & & \\
\hline $\begin{array}{l}\text { More: Slnk, Watch, and } N \\
\text { 2Average variance extrab } \\
\text { loadingsy)(Eummation of t } \\
\text { vanances) }\end{array}$ & $\begin{array}{l}\text { eds were deleied du } \\
\text { ed (AVE) - (gummat } \\
\text { e square of the facto }\end{array}$ & $\begin{array}{l}\text { low loadin } \\
\text { of the squa } \\
\text { adings) } \div \text { (s }\end{array}$ & ation & e error \\
\hline
\end{tabular}


Convergent validity is usually ascertained by loadings, average variance and composite reliability (Gholami et al. 2013). Loadings were all higher than 0.5; composite reliability higher than 0.7 and AVE greater than 0.5 (Table 2). The discriminant validity of the measures was inspected. Correlation between constructs and the square root of the average variance of each construct was observed and compared as suggested by Gholami et al., 2013. The square root of AVE is higher than correlational values (Table 3 ) indicating adequate discriminant validity (Fornell \& Larcker, 1981). Hence, the model evaluation criteria were met and its reliability and validity measures supported.

Table 3: Discriminant validity

\begin{tabular}{|lllll|}
\hline $\begin{array}{l}\text { Discriminant validity } \\
\text { of constructs }\end{array}$ & $\begin{array}{l}\text { Food } \\
\text { Service } \\
\text { Performance }\end{array}$ & $\begin{array}{l}\text { Food- } \\
\text { Hygiene } \\
\text { Practices }\end{array}$ & Holistic-View & $\begin{array}{l}\text { Perceived } \\
\text { Leadership } \\
\text { Effectiveness }\end{array}$ \\
\hline $\begin{array}{l}\text { Food Service } \\
\text { Performance }\end{array}$ & $\mathbf{0 . 7 4 2}$ & & \\
$\begin{array}{l}\text { Food-Hygiene Practice } \\
\text { Holistic View }\end{array}$ & 0.094 & $\mathbf{0 . 7 3 3}$ & & \\
$\begin{array}{l}\text { Perceived Leadership } \\
\text { Effectiveness }\end{array}$ & 0.247 & 0.149 & $\mathbf{0 . 7 9 9}$ & $\mathbf{0 . 7 8 0}$ \\
\hline $\begin{array}{l}\text { Note: Diagonal elements are the square root of the average variance extracted (AVE) between } \\
\text { the constructs and their measures. Off-diagonal elements are correlations between constructs. }\end{array}$ \\
$\begin{array}{l}\text { For discriminant validity, diagonal elements should be larger than off-diagonal elements in the } \\
\text { same row and column. }\end{array}$ \\
\end{tabular}

\subsection{Structural Model}

The structural model shows causal relationships among constructs in the model (Sang, Lee, \& Lee, 2010). Figure 1 of Table 4 shows the results of the structural model from the PLS output. Perceived Leadership Effectiveness positively relates to Holistic View $\left(R^{2}=0.088, \beta\right.$ $=0.260, p<0.01)$ and Holistic View to Food Performance $\left(R^{2}=0.061, \beta=0.247, p<0.01\right)$. These findings support $\mathrm{H} 2$ and $\mathrm{H} 3$. However, Food-Hygiene Practice $(\beta=0.114, p>0.05)$ is not a significant predictor of Holistic View. Thus, $\mathrm{H} 1$ is not supported. There is a $6.1 \%$ variance in Food Performance, so the most significant predictors are Leadership Effectiveness and Holistic View.

$\mathrm{Q}^{2}$ via blindfolding measures predictive relevance. As predicting observables is more significant than estimating constructs, part of the data was omitted during parameter estimations and then estimated (Chin 2010). Omission distance can be from 5 to $10 . \mathrm{Q}^{2}>0$ implies the model's predictive relevance whereas $Q^{2}<0$ a lack of predictive relevance 
(Fornell \& Cha, 1994). The cross-validated redundancy for two endogenous constructs, Holistic View, and Food Performance (see Figure 1) was calculated for predictive relevance (Chin, 2010). Table 5 shows $Q^{2}$ values at 0.027 and 0.044 respectively indicating the model's predictive relevance.

Table 4: Summary of results of hypotheses testing

\begin{tabular}{|llllll}
\hline Hypothesis & Relationship & Beta & $\begin{array}{l}\text { Std } \\
\text { Error }\end{array}$ & t-value & Decision \\
\hline H1 & $\begin{array}{l}\text { Food-Hygiene } \\
\text { Practices } \rightarrow \text { Holistic View }\end{array}$ & 0.114 & 0.158 & 0.723 & $\begin{array}{l}\text { Not } \\
\text { Supported }\end{array}$ \\
H2 & $\begin{array}{l}\text { Perceived Leadership } \\
\text { Effectiveness } \rightarrow \text { Holistic View }\end{array}$ & 0.260 & 0.065 & $3.992^{* * * *}$ & Supported \\
H3 & $\begin{array}{l}\text { Holistic View } \rightarrow \text { Food Service } \\
\text { Performance }\end{array}$ & 0.247 & 0.065 & $3.783^{* * *}$ & Supported \\
& & & & \\
\hline
\end{tabular}

Notes: $* * * \mathrm{p}<0.01(2.33),{ }^{*} \mathrm{p}<0.05(1.645),{ }^{*} \mathrm{p}<0.1(1.28)$; (based on the one-tailed test)

Table 5: Blindfolding result: cv-communality and cv-redundancy

\begin{tabular}{|c|c|c|}
\hline Block & $\mathrm{Cv}-$ Communality $\mathrm{H}^{2}$ & $\mathrm{Cv}$ - Redundancy $\mathrm{F}^{2}$ \\
\hline Food Performance & 0.523 & 0.027 \\
\hline Holistic View & 0.407 & 0.044 \\
\hline
\end{tabular}

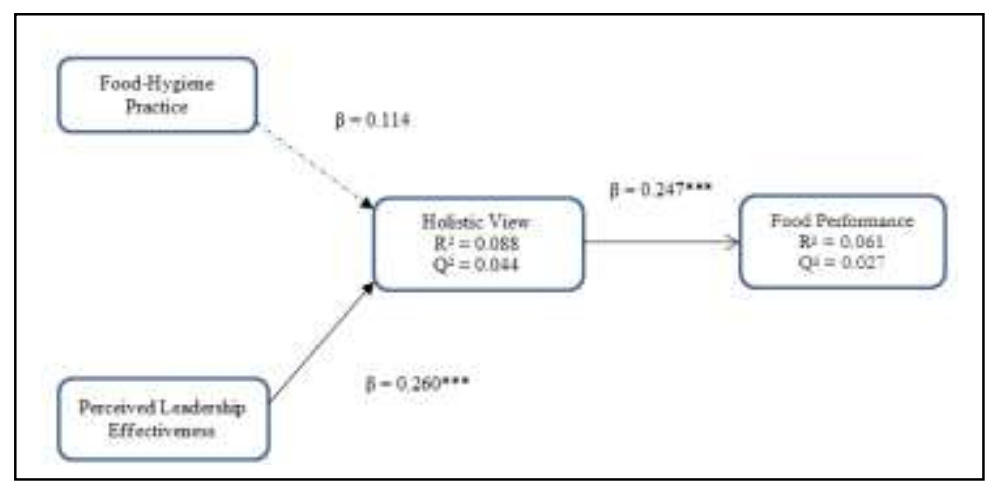

Figure 1: Hypothesis Testing Results 


\subsection{Implications of the Study}

Holistic View in this study has a positively significant relationship with performance, but not with Perceived Leadership Effectiveness. This contradicts the findings of Grunes et al. (2014) as well as discussions relating to the relationship between $\mathrm{SQ}$ and leadership (Dent et al., 2005).

The implication is that efforts should focus on nurturing food handlers with high SQ values as they would selflessly work to ensure that food prepared is always of the highest quality no matter the odds they face in the workplace. Food purveyors who are the decision makers in the food service operation should also be involved in developing Holistic View values of frontline employees so that they can deal with the complexities of food service business. Also, immediate supervisors need to find the most efficient way of delegating work that would make food handlers competent, knowledgeable and useful at work.

\subsection{Limitations of the Study}

The study results are based on data collected from public food service operations and are not generalizable to other contexts. The data is perceived-based obtained via self-reporting at the individual level. It is the food handlers and not consumers who measure Leadership Effectiveness of their immediate supervisors and Food Performance.

\subsection{Conclusion}

Perceived Leadership Effectiveness of immediate superiors can develop holistic values of younger food handlers. Strong and convincing leaders can influence subordinates to work effectively. Also, food handlers with holistic values have a distinct work identity, are more aware of roles and responsibilities, and tend to improve food performance. Nevertheless, food handling activities did not bring about any holistic effect on food handlers who seemed preoccupied with daily food preparation.

Future research could examine why Food-Hygiene Practices do not affect Holistic View. One possibility is to test the relationship using formative measures on Food-Hygiene Practice items. Also, the effect of Food-Hygiene practices on other values like self-consciousness, high-consciousness and challenge could be studied instead. Finally, a study could be done on how values of Holistic View could help front-line employees deal with complex food service situations.

\section{References}

Ayranci, E. (2011). Effects of top Turkish managers' emotional and spiritual intelligences on their organizations' financial performance. Business Intelligence Journal, 4(1), 9-32.

Barrera, T. L., Zeno, D., Bush, A. L., Barber, C. R., \& Stanley, M. A. (2012). Integrating Religion and Spirituality Into Treatment for Late-Life Anxiety: Three Case Studies. Cognitive and Behavioral Practice, 19(2), 346-358. doi: http://dx.doi.org/10.1016/j.cbpra.2011.05.007 
Bolton, D. J., Meally, A., Blair, I. S., McDowell, D. A., \& Cowan, C. (2008). Food safety knowledge of head chefs and catering managers in Ireland. Food Control, 19, 291-300.

Chin, W. W. (2010). How to write up and report PLS analyses. In W. W. C. In V. Esposito Vinzi, J. Henseler, H. Wang (Ed.), Handbook of partial least squares: Concepts, methods and application (pp. 691-711). New York: Springer.

Croasmun, J. T., \& Ostrom, L. (2011). Using Likert-type scales in the social sciences. Journal of Adult Education, 40(1), $19-22$.

Dent, E. B., Higgins, M. E., \& Wharff, D. M. (2005). Spirituality and leadership: an empirical review of definitions, distinctions, and embedded assumptions. The Leadership Quarterly, 16, 625-653.

Eliasi, J. R., \& Dwyer, J. T. (2002). Kosher and Halal: religious observances affecting dietary intakes. Journal of The American Dietetic Association, 911-913.

Fornell, C., \& Cha, J. (1994). Partial Least Squares. In P. R, Bagozzi (Ed.), Advanced Methods of Marketing Research (pp. 52-78). Oxford: Blackwell.

Fornell, C., \& Larcker, D. F. (1981). Evaluating structural equation models with unobservable variables and measurement error. Journal of Marketing Research, 18(1), 39-50.

Fry, L. W. (2003). Toward a theory of spiritual leadership. The Leadership Quarterly, 14, 693-727.

George, M. (2006). Practical application of spiritual intelligence in the workplace. Human Resource management International Digest, 14(5), 3-5.

Gholami, R., Sulaiman, A. B., Ramayah, T., \& Molla, A. (2013). Senior managers' perception on green information systems (IS) adoption and environmental performance: Results from a field survey. Information and Management, 50(7), 431-438.

Grunes, P., Gudmundsson, A., \& Irmer, B. (2014). To what extent is the Mayer and Salovey (1997) model of emotional intelligence a useful predictor of leadership style and perceived leadership outcomes in Australian educational institutions? Educational Management Administration \& Leadership, 42(1), 112-135.

Gupta, M., Kumar, V., \& Singh, M. (2014). Creating satisfied employees through workplace spirituality: a study of a private insurance sector in Punjab (India). Journal Business Ethics, 122, 79-88.

Joseph F. Hair, J., Hult, G. T. M., Ringle, C. M., \& Sarstedt, M. (2014). A Primer on Partial Least Squares Structural Equation Modeling (PLS-SEM). Los Angeles. London. New Delphi. Singapore. Washington DC: SAGE Publications, Inc.

Kadkhoda, M., \& Jahani, H. (2012). Problem-solving capacities of spiritual intelligence for artificial intelligence. Procedia - Social and Behavioral Sciences, 32(0), 170-175. doi: http://dx.doi.org/10.1016/j.sbspro.2012.01.027

Kleynhans, H. C. (2003). Leisure tourists' satisfaction regarding their meal experience at Lesedi Cultural Village. (Master in Consumer Science), University of Pretoria, Pretoria. (etd-02252004-092144)

Kumar, S., \& Bhasin, A. (2014). The relationship between spirituality and workplace emotional intelligence: implications for individuals in organizations. International Journal of Management and Social Science Research Review, 1(3), 47-55. 
Lewis, G. J., Ritchie, S. J., \& Bates, T. C. (2011). The relationship between intelligence and multiple domains of religious belief: Evidence from a large adult US sample. Intelligence, 39(6), 468-472. doi: http://dx.doi.org/10.1016/j.intell.2011.08.002

Magnusson, D., \& Torestad, B. (1993). A holistic view of personality: a model revisited. Annu. Rev. Psychol., 44, 452.

Marques, J. F. (2005). Socializing a capitalistic world: redifining the bottom line. Journal of American Academy og Business, 7(1), 283.

Mazni, S., Toh, P. S., Mohamed Azam, M. A., \& Siti Khadijah, A. M. (2014, 2-3 September 2013). Perceived leadership effectiveness on food handlers' spiritual intelligence in food service business. Paper presented at the Hospitality and Tourism Postgraduate Conference 2013, Shah Alam, Malaysia.

Mazni, S., Toh, P. S., Mohd Faiz Foong, A., \& Norazmir, M. N. (2013). Use of rapid microbial kits for regular monitoring of food-contact surfaces towards hygiene practices. Procedia - Social and Behavioral Sciences, 105, 273-283.

McAdamis, E. M. (2011). Astrosociology and the Capacity of Major World Religions to Contextualize the Possibility of Life Beyond Earth. Physics Procedia, 20(0), 338-352. doi: http://dx.doi.org/10.1016/j.phpro.2011.08.031

Mortell, M., Balkhy, H. H., Tannous, E. B., \& Jong, M. T. (2013). Physician 'defiance' towards hand hygiene compliance: Is there a theory-practice-ethics gap? Journal Saudi Heart Association 25, 203-208.

Ramayah, T., Lee, J. W. C., \& Boey, C. I. (2011). Network collaboration and performance in the tourism sector. Service Business, 5(4), 411-428.

Ramayah, T., Yeap, J. A. L., \& Ignatius, J. (2013). An empirical inquiry on knowledge sharing among academicians in higher learning institutions. Minerva: A Review of Science, Learning and Policy, 51(2), 131-154.

Ringle, C. M., Wende, S., \& Becker, J.-M. (2014). SmartPls 3.0. Retrieved 23 October 2014, from http:/www.smartpls.com

Ronay, R., \& Carney, D. R. (2013). Testosterone's negative relationship with empathic accuracy and perceived leadership ability. Social Psychological and Personality Science, 4(1), 92-99.

Rostami, A. M., \& Gol, H. C. (2014). Prediction of Marital Satisfaction based on Spiritual Intelligence. Procedia Social and Behavioral Sciences, 116(0), 2573-2577. doi: http://dx.doi.org/10.1016/i.sbspro.2014.01.613

Sang, S., Lee, J. D., \& Lee, J. (2010). E-government adoption in Cambodia: A partial least squares approach. Transforming government: People, process and policy, 4(2), 138-157.

Vayalilkarottu, J. (2012). Holistic health and well-being: A psycho-spiritual/religious and theological perspective. Asian Journal of Psychiatry, 5(4), 347-350. doi: http://dx.doi.org/10.1016/j.ajp.2012.09.010

Yukl, G. (2008). How leaders influence organizational effectiveness. The Leadership Quarterly, 19(6), 708-722. doi: http://dx.doi.org/10.1016/j.leaqua.2008.09.008

Zohar, D., \& Marshall, I. (2001). Spiritual Intelligence the Ultimate Intelligence. London: Bloomsbury Publishing. 